\title{
Modulation of the bipolar seesaw in the Southeast Pacific during Termination 1
}

\author{
Frank Lamy $^{\mathrm{a}, *}$, Jérôme Kaiser ${ }^{\mathrm{b}}$, Helge W. Arz ${ }^{\mathrm{b}}$, Dierk Hebbeln ${ }^{\mathrm{c}}$, Ulysses Ninnemann ${ }^{\mathrm{d}}$, \\ Oliver Timm $^{\mathrm{e}}$, Axel Timmermann ${ }^{\mathrm{e}}$, J.R. Toggweiler ${ }^{\mathrm{f}}$ \\ a Alfred-Wegener-Institute for Polar and Marine Research, Am Alten Hafen 26, 27568 Bremerhaven, Germany \\ b GeoForschungsZentrum-Potsdam, Telegrafenberg, 14473 Potsdam, Germany \\ ${ }^{c}$ MARUM - Center for Marine Environmental Sciences, University of Bremen, Leobener Strasse, 28359 Bremen, Germany \\ d Bjerknes Centre for Climate Research, University of Bergen, Allégaten 55, 5007 Bergen, Norway \\ e IPRC, SOEST, University of Hawaiti at Manoa, 2525 Correa Road, Honolulu, HI 96822, USA \\ ${ }^{\mathrm{f}}$ Geophysical Fluid Dynamics Laboratory, National Oceanic and Atmospheric Administration, P.O. Box 308, Princeton, NJ 08542, USA
}

Received 30 January 2007; received in revised form 25 April 2007; accepted 26 April 2007

Available online 8 May 2007

Editor: H. Elderfield

\begin{abstract}
The termination of the last ice age (Termination 1; T1) is crucial for our understanding of global climate change and for the validation of climate models. There are still a number of open questions regarding for example the exact timing and the mechanisms involved in the initiation of deglaciation and the subsequent interhemispheric pattern of the warming. Our study is based on a well-dated and high-resolution alkenone-based sea surface temperature (SST) record from the SE-Pacific off southern Chile (Ocean Drilling Project Site 1233) showing that deglacial warming at the northern margin of the Antarctic Circumpolar Current system (ACC) began shortly after 19,000 years BP (19 kyr BP). The timing is largely consistent with Antarctic ice-core records but the initial warming in the SE-Pacific is more abrupt suggesting a direct and immediate response to the slowdown of the Atlantic thermohaline circulation through the bipolar seesaw mechanism. This response requires a rapid transfer of the Atlantic signal to the SE-Pacific without involving the thermal inertia of the Southern Ocean that may contribute to the substantially more gradual deglacial temperature rise seen in Antarctic ice-cores. A very plausible mechanism for this rapid transfer is a seesawinduced change of the coupled ocean-atmosphere system of the ACC and the southern westerly wind belt. In addition, modelling results suggest that insolation changes and the deglacial $\mathrm{CO}_{2}$ rise induced a substantial SST increase at our site location but with a gradual warming structure. The similarity of the two-step rise in our proxy SSTs and $\mathrm{CO}_{2}$ over T1 strongly demands for a forcing mechanism influencing both, temperature and $\mathrm{CO}_{2}$. As SSTs at our coring site are particularly sensitive to latitudinal shifts of the ACC/southern westerly wind belt system, we conclude that such latitudinal shifts may substantially affect the upwelling of deepwater masses in the Southern Ocean and thus the release of $\mathrm{CO}_{2}$ to the atmosphere as suggested by the conceptual model of [Toggweiler, J.R., Rusell, J.L., Carson, S.R., 2006. Midlatitude westerlies, atmospheric $\mathrm{CO}_{2}$, and climate change during ice ages. Paleoceanography 21. doi:10.1029/2005PA001154].
\end{abstract}

(C) 2007 Elsevier B.V. All rights reserved.

Keywords: paleooceanography; Termination 1; Southeast Pacific; bipolar seesaw; alkenones

\footnotetext{
* Corresponding author. Tel.: +4947148312121; fax: +4947148311923.
}

E-mail address: flamy@awi-bremerhaven.de (F. Lamy). 


\section{Introduction}

The termination of the last ice age (Termination 1; T1) is the last major climate transition of the Earth's recent geological history and is thus crucial for our understanding of recent climate processes and the validation of climate models. Though $\mathrm{T} 1$ is accordingly very well studied involving numerous proxy records from both marine and terrestrial archives (e.g., Alley and Clark, 1999; Clark et al., 1999, 2004; Rinterknecht et al., 2006) as well as modelling studies (e.g., Knorr and Lohmann, 2003; Weaver et al., 2003), there are still a number of open questions regarding for example the exact timing and the mechanisms involved in the initiation of deglaciation and the subsequent interhemispheric pattern of the warming. Based on the Milankovitch concept, the ultimate drivers for the glacial termination are the increase in Northern Hemisphere (NH) summer insolation and non-linear responses from continental ice-sheets and particularly atmospheric greenhouse gases such as $\mathrm{CO}_{2}$ that transfer the northern signal globally (e.g. Clark et al., 1999). However, it has also been repeatedly suggested that the Southern Hemisphere (SH) leads the deglaciation and warming in the NH (e.g., Bard et al., 1997), whereas a reevaluation of available ice-core and marine records covering T1 (Alley et al., 2002) suggests a northern temperature lead on orbital time-scales.

Part of the divergent views on possible interhemispheric leads or lags during $\mathrm{T} 1$ arise from the pronounced millennial-scale variations that are superimposed on primarily insolation-driven orbital-scale changes and are markedly different between the $\mathrm{NH}$ and $\mathrm{SH}$. The general warming trend that may start as early as 23,000 years before present (23 kyr BP), based on Greenland and Antarctic ice-core records (e.g., Alley and Clark, 1999; Blunier and Brook, 2001), is further accentuated between $\sim 17$ and $19 \mathrm{kyr}$ BP in the south, whereas $\mathrm{NH}$ records show a return to cold conditions that culminate at the time of Heinrich event (HE) 1 (e.g., Alley and Clark, 1999). Thereafter, NH temperature abruptly increased into the Bølling/Allerød (B/A) warm period. In Antarctica, the deglacial warming trend was partly interrupted by a millennial-scale cooling event (Antarctic Cold Reversal, ACR) that began around the time of the B/A warming and ended close to the beginning of the Younger Dryas (YD) cold phase observed in the NH (e.g., Blunier and Brook, 2001; Morgan et al., 2002). The present picture of climate pattern during $\mathrm{T} 1$ is thus largely focussed on high latitude records in particular from Greenland and Antarctic ice-cores that have been synchronized by correlating globally recordable methane fluctuations (e.g., Blunier and Brook, 2001; Morgan et al., 2002; Epica Community Members, 2006). However, this correlation reveals ambiguities over the interval of the beginning deglacial warming in the $\mathrm{SH}$ making the analysis of interhemispheric climate pattern over this important interval more difficult.

Marine records from the SH have been involved to a much lesser extent. The available data from the Southern Ocean (e.g., Bianchi and Gersonde, 2004; Shemesh et al., 2002) and southern mid-latitudes (e.g., Pahnke et al., 2003) are generally consistent with the Antarctic records but dating uncertainties are high due to scarce datable material and/or large and potentially variable ${ }^{14} \mathrm{C}$ reservoir ages. In addition, an increasing number of high-resolution records from the tropics have recently become available (e.g., Lea et al., 2006; Visser et al., 2003). As deglacial warming in some of these records occurred largely in phase with the $\mathrm{CO}_{2}$ increase as observed in Antarctic ice-cores, they have been interpreted in support for a tropical "trigger" for the deglaciation (Visser et al., 2003).

In this paper, we attempt to better understand the sequence of events over the last termination, on an absolute time-scale, based on a new sea surface temperature (SST) record from the SE-Pacific with exceptional time-resolution and dating accuracy over T1 (i.e., 10-25 kyr BP). Our SST data are from Ocean Drilling Project (ODP) Site 1233 located at the southern Chilean continental margin at $41^{\circ} \mathrm{S}$ within the northernmost reach of the Antarctic Circumpolar Current (ACC) and the southern westerly wind belt (Fig. 1). In previous works, we showed that the complete $\sim 70$-kyr-long alkenone SST record at Site 1233 closely follows millennial-scale temperature fluctuations as observed in Antarctic ice cores (Kaiser et al., 2005; Lamy et al., 2004). However, the absolute age-scale over the earlier part of the last glacial, when large amplitude methane fluctuations allow a detailed inter-correlation of Greenland and Antarctic ice-cores (Blunier and Brook, 2001; Epica Community Members, 2006), is less well defined in marine sediments due to increasing uncertainties in radiocarbon dating and calendar year conversion. Therefore, we now substantially increased the time resolution around $\mathrm{T} 1$, an interval that spans $\sim 27 \mathrm{~m}$ composite core depth at Site 1233, and added a number of new ${ }^{14} \mathrm{C}$ AMS dates, now with an average spacing of $\sim 1200$ years.

\section{Investigation area}

Site $1233\left(41^{\circ} 00^{\prime} \mathrm{S} ; 74^{\circ} 27^{\prime} \mathrm{W}\right)$ is located $38 \mathrm{~km}$ offshore (20 km off the continental shelf) at $838 \mathrm{~m}$ water 
depth in a small forearc basin on the upper continental slope off Southern Chile (Fig. 1) away from the pathway of major turbidity currents (Mix et al., 2003). The region is located within the northernmost reach of the Antarctic Circumpolar Current (ACC) at the origin of the PeruChile Current (PCC) (Fig. 1). The ACC brings cold, relatively fresh, nutrient-rich, Subantarctic Surface Water originating from the region north of the Subantarctic Front. The northern part of the ACC splits around $\sim 43^{\circ} \mathrm{S}$ into the PCC flowing northward and the Cape-Horn Current (CHC) turning towards the south (Strub et al., 1998). The mean annual SST at $\sim 41^{\circ} \mathrm{S}$
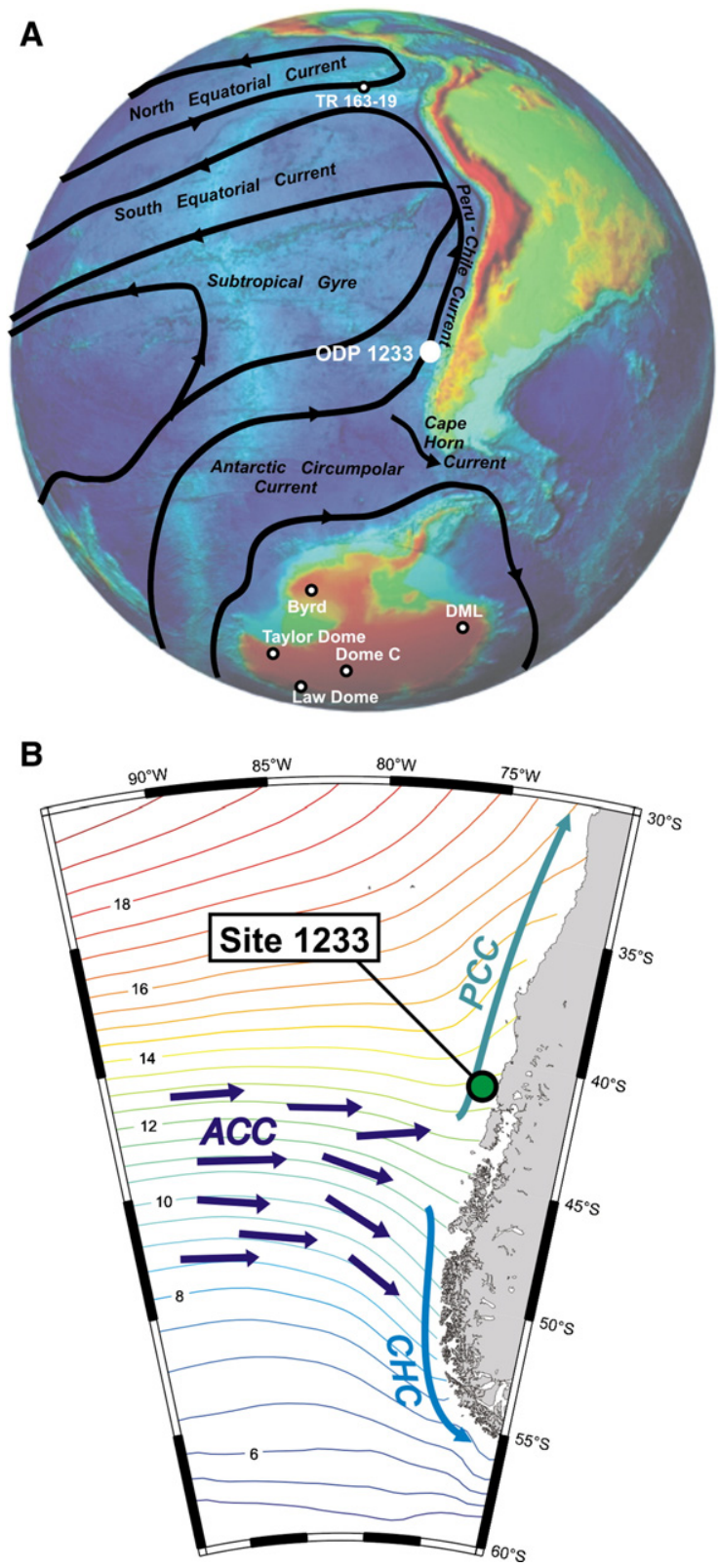

(ODP Site 1233) is $\sim 14{ }^{\circ} \mathrm{C}$ and varies between $\sim 11^{\circ} \mathrm{C}$ in winter and $\sim 16{ }^{\circ} \mathrm{C}$ in summer, i.e. with a seasonal amplitude of $\sim 5^{\circ} \mathrm{C}$. Linked to the northern boundary of the ACC, steep latitudinal SST gradients occur south of Site 1233 , a region that is increasingly influenced by the southern westerly wind belt (Fig. 1). Northward, the SST isotherms take a more meridional orientation, primarily as a result of the equatorward advection of cold water in the PCC and to a lesser extent as a direct consequence of increasing coastal upwelling towards the central and northern Chilean margin (Tomczak and Godfrey, 2003).

\section{Material, methods, and chronology}

\subsection{Sampling}

Five Advanced Piston Corer holes were drilled at Site 1233 to ensure a complete stratigraphic overlap between cores from different holes. Detailed comparisons between high-resolution core logging data performed shipboard demonstrated that the complete sedimentary sequence down to 116.4 meters below surface (mbsf) was recovered. Based on these data, a composite sequence (the so-called splice) was constructed representing 135.65 meters composite depth (mcd). Discrete samples for alkenone analyses were taken from the interval that covers Termination 1 (T1) (see age model) with an average resolution of $\sim 15 \mathrm{~cm}$ resulting in a temporal resolution of $\sim 90$ years of our alkenone SST record. Additional samples for ${ }^{14} \mathrm{C}$ accelerator mass spectrometry (AMS) dating were taken from the splice and, in some cases, from outside the splice.

\subsection{Age model}

In this study we present data from the composite sequence between 10 and 5 thousand calendar years

Fig. 1. (A) Map of the South Pacific Ocean and adjacent areas showing major surface currents (after Tomczak and Godfrey, 2003) and the location of marine sediment cores (TR163-19 from the tropical eastern Pacific (Lea et al., 2006; Spero and Lea, 2002); ODP 1233 from the Southeast Pacific (this study)) and ice-cores (Byrd (Blunier and Brook, 2001); Dome C (Epica Community Members, 2004); Dronning Maud Land (DML) (Epica Community Members, 2006); Law Dome (Morgan et al., 2002); Taylor Dome (Indermühle et al., 2000)) discussed in the paper. (B) Annual mean SST $\left({ }^{\circ} \mathrm{C}\right)$ distribution in the Southeast Pacific between $30^{\circ} \mathrm{S}$ and $60^{\circ} \mathrm{S}$ (NOAA-CIRES Climate Diagnostics Center (http://www.cdc.noaa.gov/index.html)) and location of ODP Site 1233 at the northern margin of the ACC. The contour interval is $0.5{ }^{\circ} \mathrm{C}$. Further shown is a simplified view of the major current systems $(\mathrm{PCC}=$ Peru-Chile Current; $\mathrm{ACC}=$ Antarctic Circumpolar Current; $\mathrm{CHC}=$ Cape Horn Current). 
before present (kyr BP) representing $\sim 13$ mod to $\sim 40$ mcd. The age model of this interval is based on thirteen ${ }^{14} \mathrm{C}$ AMS datings (Table 1) with an average spacing of $\sim 1200$ years and linear interpolation between the dates. ${ }^{14} \mathrm{C}$ ages were primarily calibrated with the INTCALO4 calibration curve (Reimer et al., 2004). However, the INTCALO4 calibration curve is poorly constrained for the interval between $\sim 12,500$ and $\sim 14,500{ }^{14} \mathrm{C}$ yr BP with few data points and missing surface coral data (Robinson et al., 2005) (Fig. 2). Radiocarbon data from the Cariaco basin (Hughen et al., 2004) suggest the presence of a radiocarbon plateau lasting from $\sim 12,900$ to $\sim 13,300{ }^{14} \mathrm{C}$ yr BP $(\sim 15.7$ to $\sim 17$ kyr BP) (Fig. 2). Similar results have been obtained from a densely ${ }^{14} \mathrm{C}$-dated marine sediment core in the Northwest Pacific (Sarnthein et al., 2006). Likewise, two of our ${ }^{14} \mathrm{C}$ AMS datings (at $21.39 \mathrm{mcd}$ and $23.69 \mathrm{mcd}$ ) within this interval revealed ${ }^{14} \mathrm{C}$-ages very close together that would result in anomalously high sedimentation rates (Table 1). Therefore, we applied here the CalPal_SFCP_2005 (www.calpal.de) calibration curve which is primarily based on the Cariaco basin record (Hughen et al., 2004) in this interval and contains a number of data points (Fig. 2). For the CalPal_SFCP_2005 calibration curve, the original GISP2synchronized gray-scale record has been adapted to the Greenland time-scale of Shackleton et al. (2004). This has been done by linearly interpolating between the unchanged base of the Bølling/Allerød at $14.66 \mathrm{kyr}$ BP and the base of Greenland interstadial at $29 \mathrm{kyr}$ BP (compared to $27.84 \mathrm{kyr} \mathrm{BP}$ in the original synchronization to GISP2 (Hughen et al., 2004)). Within the for this study relevant interval the offset is however very small.

Table 1 compares the calibrated ages using different calibration curves (including CalPal_SFCP_2005, INTCAL04, and the most recent Fairbanks U/Th-based calibration curve (Fairbanks et al., 2005)). Except for the above mentioned interval, the calibrated ages are nearly indistinguishable making the timing of the first and second major warming step discussed in this paper very robust. Calendar ages derived with the CalPal_SFCP_2005 calibration curves are however significantly older for three datings within the poorly constrained interval in the coral-based calibration curves. The presence of the above mentioned radiocarbon plateau induces a significant uncertainty in the calibrated ages of the dating at $23.69 \mathrm{mcd}$. However, the sedimentation-rates achieved by calibrating the ${ }^{14} \mathrm{C}$ datings with the CalPal_SFCP_2005 calibration curve appear more realistic assuming only moderately variable sedimentation rates at Site 1233 as shown by the other datings (Table 1).
As discussed in detail in our previous publications (Kaiser et al., 2005; Lamy et al., 2004), we assume no regional deviation from the global reservoir effect of $\sim 400$ years because of the presence of an early Holocene volcanic ash layer at Site 1233 (that has been likewise dated on land) and the position of our site significantly south of the Chilean upwelling zone (Strub et al., 1998) and north of the southern polar front where higher reservoir ages may be expected. In addition, the new datings presented in this paper that fall on the above mentioned radiocarbon plateau support the $\sim 400$ years reservoir age assumption. Larger reservoir ages would move the corrected ${ }^{14} \mathrm{C}$-ages after the plateau (Fig. 2) and would thus yield anomalous sedimentation rates (Table 1).

We revised all radiocarbon-based age models of published studies shown in our paper as outlined above for our own datings. All ice-core age models are plotted on the new Greenland Ice Core Chronology 2005 (GICC05) that is based on annual layer counting back to 42 kyr BP (Andersen et al., 2006). The Epica Dronning Maud Land (DML) and Byrd ice-cores have been synchronized to the Greenland record using the pattern of millennial-scale methane fluctuations (Epica Community Members, 2006; Blunier et al., 2007). The iceage scale of the Epica Dome C (Dome C) record has been synchronized to that of DML using volcanic and dust tie points based on continuous sulfate, electrolytic conductivity, dielectric profiling, particulate dust, and $\mathrm{Ca}^{2+}$ data available for both cores (Epica Community Members, 2006). A gas-age model based on the GICC05 for Dome C has not yet been published. We therefore synchronized the Dome C and DML methane records taking a minimum number of tie-points at the large fluctuations around the $\mathrm{YD}$ and $\mathrm{B} / \mathrm{A}$ and a minor peak in methane close to $23 \mathrm{kyr}$ BP (Fig. 3).

\subsection{Alkenone measurements}

Alkenones were extracted from 1 to $3 \mathrm{~g}$ of freezedried and homogenized sediment following a procedure described in detail by Müller et al. (1998). The extracts were analysed by capillary gas chromatography using an HP 5890 serie II Plus gas chromatograph equipped with a 60-m column (J\&W DB5MS, $0.32 \mathrm{~mm} \times 0.1 \mu \mathrm{m}$ ), split/splitless and flame ionization detection. Helium was used as carrier gas with a constant pressure of $150 \mathrm{kPa}$. The oven temperature was programmed to reach $50-250{ }^{\circ} \mathrm{C}$ at $25{ }^{\circ} \mathrm{C} / \mathrm{min}, 250-290$ at $1{ }^{\circ} \mathrm{C} / \mathrm{min}$, followed by a plateau of $26 \mathrm{~min}$, and $290-310$ at $30{ }^{\circ} \mathrm{C} /$ $\min$, with the final temperature being maintained for $10 \mathrm{~min}$. 
Table 1

${ }^{14} \mathrm{C}$ ages obtained by accelerator mass spectrometry dating of mixed planktonic foraminifera samples (primarily Globigerinoides bulloides and Neogloboquadrina pachyderma), performed at the Leibniz-Labor AMS facility in Kiel, Germany

\begin{tabular}{|c|c|c|c|c|c|c|c|c|c|c|c|c|}
\hline \multirow[t]{2}{*}{ Lab. ID } & \multirow{2}{*}{$\begin{array}{l}\text { Core depth } \\
\text { (mcd) }\end{array}$} & \multirow{2}{*}{$\begin{array}{l}{ }^{14} \mathrm{C} \text {-age } \\
(\mathrm{kyr})\end{array}$} & \multirow{2}{*}{$\begin{array}{l} \pm \text { Error } \\
\text { (kyr) }\end{array}$} & \multicolumn{6}{|l|}{ Calendar ages (kyr) } & \multicolumn{3}{|c|}{ Sedimenation rates $(\mathrm{m} / \mathrm{kyr})$} \\
\hline & & & & CalPal_SFCP_2005 & $\begin{array}{l} \pm \text { Error } \\
(\mathrm{kyr})\end{array}$ & INTCAL04 & $\begin{array}{l} \pm \text { Error } \\
(\mathrm{kyr})\end{array}$ & Fairbanks & $\begin{array}{l} \pm \text { Error } \\
\text { (kyr) }\end{array}$ & CalPal_SFCP_2005 & INTCAL04 & Fairbanks \\
\hline KIA 21451 & 12.94 & 8.94 & 0.08 & 10.05 & 0.13 & $10.05^{*}$ & 0.13 & 10.05 & 0.13 & 1.88 & 1.88 & 1.88 \\
\hline KIA 29613 & 14.21 & 9.47 & 0.043 & 10.75 & 0.1 & $10.72 *$ & 0.07 & 10.72 & 0.08 & 1.81 & 1.90 & 1.90 \\
\hline KIA 21473 & 17.01 & 10.4 & 0.07 & 12.33 & 0.17 & $12.33^{*}$ & 0.18 & 12.33 & 0.16 & 1.77 & 1.74 & 1.74 \\
\hline KIA 21447 & 20.22 & 11.88 & 0.07 & 13.76 & 0.11 & $13.75^{*}$ & 0.06 & 13.83 & 0.05 & 2.24 & 2.26 & 2.14 \\
\hline KIA 29614 & 21.39 & 12.78 & 0.055 & $15.26 *$ & 0.11 & 15.09 & 0.06 & 15.02 & 0.07 & 0.78 & 0.87 & 0.98 \\
\hline KIA 29615 & 23.69 & 13.09 & 0.06 & $16.13 *$ & 0.4 & 15.47 & 0.09 & 15.41 & 0.08 & 2.64 & 6.05 & 5.90 \\
\hline KIA 21448 & 25.1 & 14.02 & 0.11 & $17.35^{*}$ & 0.07 & 16.72 & 0.14 & 16.73 & 0.19 & 1.16 & 1.13 & 1.07 \\
\hline KIA 29616 & 27.97 & 15.35 & 0.07 & 18.68 & 0.08 & $18.73^{*}$ & 0.05 & 18.65 & 0.04 & 2.16 & 1.43 & 1.49 \\
\hline KIA 19693 & 29.81 & 16.67 & 0.11 & 19.93 & 0.27 & $19.77 *$ & 0.14 & 19.81 & 0.16 & 1.47 & 1.77 & 1.59 \\
\hline KIA 29617 & 31.47 & 17.41 & 0.09 & 20.91 & 0.38 & $20.54 *$ & 0.1 & 20.61 & 0.15 & 1.69 & 2.16 & 2.08 \\
\hline KIA 19694 & 33.51 & 18.12 & 0.125 & 21.87 & 0.2 & $21.57 *$ & 0.24 & 21.68 & 0.22 & 2.13 & 1.98 & 1.91 \\
\hline KIA 19695 & 36.56 & 19.34 & 0.135 & 23.1 & 0.27 & $23^{*}$ & 0.26 & 23.09 & 0.29 & 2.48 & 2.13 & 2.16 \\
\hline KIA 19702 & 39.5 & 20.68 & 0.15 & 24.64 & 0.23 & $24.9 *$ & 0.3 & 24.73 & 0.27 & 1.91 & 1.55 & 1.79 \\
\hline
\end{tabular}

Shown are the calendar ages and resulting linear sedimentation rates based on the CalPal_SFCP_2005 (www.calpal.de) primarily based on the GISP2-synchronized Cariaco basin record (Hughen et al., 2004) INTCAL04 (Reimer et al., 2004), and the most recent Fairbanks U/Th-based calibration curve (Fairbanks et al., 2005). Marked in red is one dating that is affected by the radiocarbon plateau shown by the CalPal_SFCP_2005 calibration curve (see Fig. 2 and discussion in Section 3.2).

* Mark calibrated ages used for the final age model. 


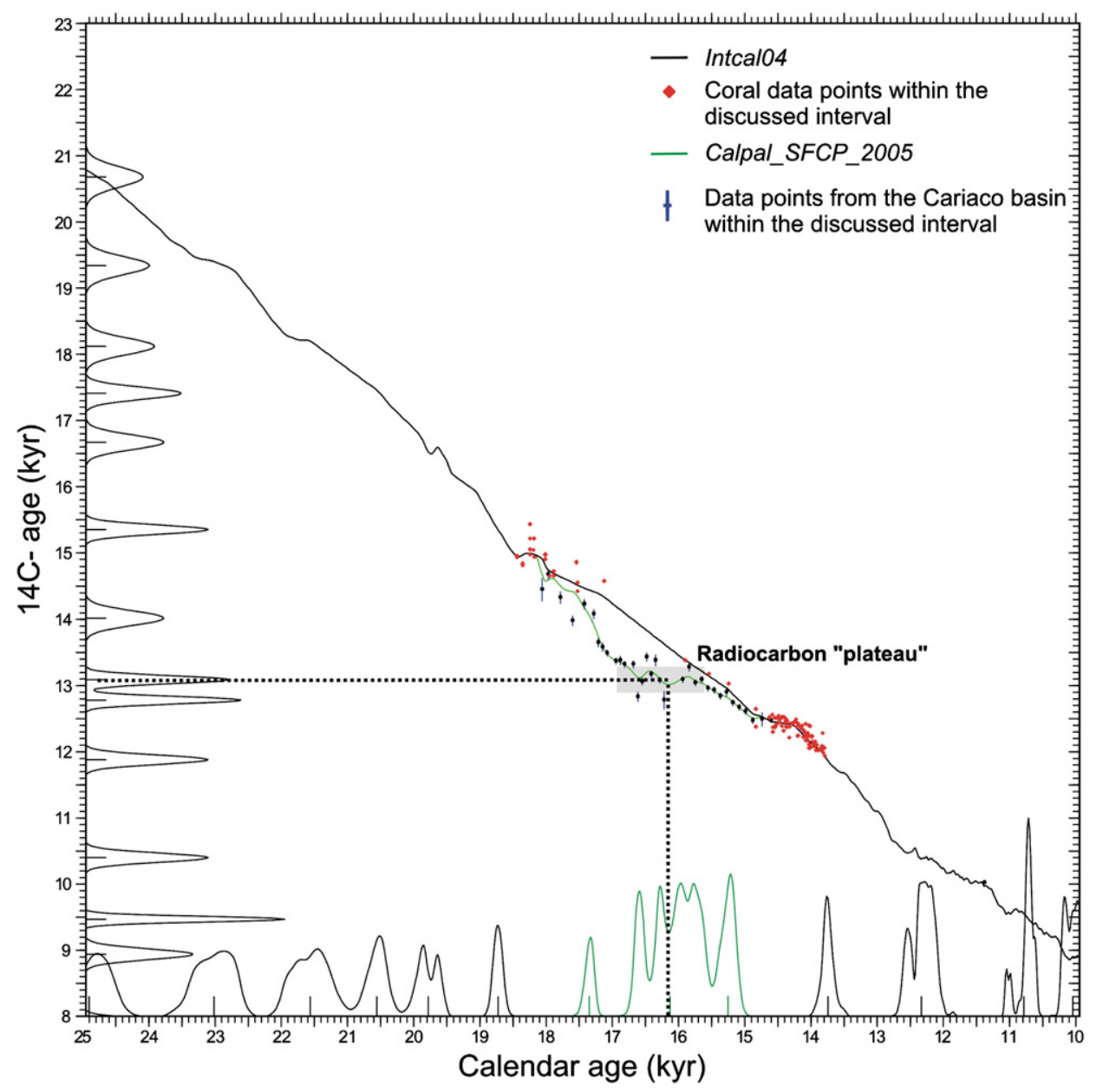

Fig. 2. Calibration of ${ }^{14} \mathrm{C}$ AMS dates over Termination $1 .{ }^{14} \mathrm{C}$ ages were primarily calibrated with the INTCAL04 calibration curve (Reimer et al., 2004) (calibration results are indicated by black bars with probability distribution). However, the INTCALO4 calibration curve is poorly constrained for the interval between $\sim 12,500$ and $\sim 14,500{ }^{14} \mathrm{C}$ yr BP with few data points and missing surface coral data (Robinson et al., 2005). For this interval, we used the CalPal_SFCP_2005 (www.calpal.de) calibration curve (green bars with probability distribution). Doted lines mark one date that is substantially influenced by the radiocarbon plateau evident in the CalPal_SFCP_2005 that derives from the Cariaco basin data points (Hughen et al., 2004) in this interval. (For interpretation of the references to colour in this figure legend, the reader is referred to the web version of this article.)

Quantification of the alkenones was achieved using 2-nonadecanone $\left(\mathrm{C}_{19} \mathrm{H}_{38} \mathrm{O}\right)$ as internal standard and HPGC ChemStation as analytical software. The alkenone unsaturation index $\mathrm{UK}_{37}^{\prime}$ was calculated from $\mathrm{UK}_{37}^{\prime}=\left(\mathrm{C}_{37: 2}\right) /\left(\mathrm{C}_{37: 3}+\mathrm{C}_{37: 2}\right)$, where $\mathrm{C}_{37: 2}$ and $\mathrm{C}_{37: 3}$ are the di- and tri-unsaturated $\mathrm{C}_{37}$ methyl alkenones. The analytical precision was estimated to be $\pm 0.3{ }^{\circ} \mathrm{C}$. For conversion into temperature values, we used the culture calibration of Prahl et al. (1988) $\left(\mathrm{UK}_{37}^{\prime}=0.034 \mathrm{~T}+\right.$ 0.039 ), which has been validated by core-top compilations (e.g., Müller et al., 1998). We assume that alkenone-derived SST estimates at Site 1233 reflect annual mean sea surface temperatures as suggested by measurements on surface sediments at Site 1233 and further north along the Chilean continental margin (Kaiser et al., 2005; Kim et al., 2002). This does, however, not exclude that alkenone SSTs could be biased towards the spring bloom in productivity.

It has been recently observed that alkenones may be substantially older than co-occurring planktic foraminifera (Mollenhauer et al., 2005). Holocene age differences measured on the Site 1233 survey core GeoB 3313-1 showed rather constant age offsets of $\sim 1000$ years (Mollenhauer et al., 2005). Mollenhauer et al. (2005) explained this offset as most likely resulting from continuous resuspension/redeposition cycles induced by internal tides and sediment focusing in morphologic depressions such as the small basin at Site 1233. By 


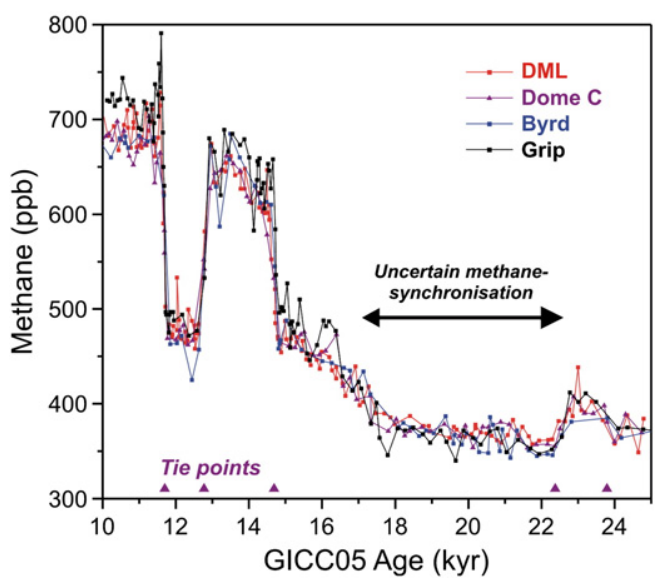

Fig. 3. Illustration of the methane synchronization for Antarctic ice core records. The Byrd, Dome C, and Dronning Maud Land (DML) records are synchronized to the Greenland GRIP record (Epica Community Members, 2006; Blunier et al., 2007) based on the layer counted GICC05 (Andersen et al., 2006). Note that the methane synchronization is uncertain for the interval from $\sim 17$ to $23 \mathrm{kyr}$ BP. Triangles show tie points used for the methane synchronization of DML and Dome C.

comparing the age offsets in different continental margin settings, they further noted that age offsets were largest where TOC contents and alkenone concentrations are highest. Therefore, we expect that the age offsets if they are indeed induced by resuspension/redeposition cycles should be much smaller for the deglacial section where both TOC and alkenone concentrations are significantly lower than during the Holocene. Alkenone concentrations are in the order of 2000 to $3000 \mathrm{ng} / \mathrm{g}$ dry sediment during the Holocene and 500 to $1000 \mathrm{ng} / \mathrm{g}$ dry sediment during the late glacial. TOC contents range from Holocene values between $\sim 1.5$ and $\sim 2.5$ wt. $\%$ to late glacial values between $\sim 0.5$ and $\sim 1$ wt.\% (Kaiser et al., 2005; Martinez et al., 2006). We also note that Holocene grainsize data on the survey core GeoB 3313-1 suggest constant and rather undisturbed fine-grained hemipelagic sedimentation (Lamy et al., 2001). Available oceanographic data show that bottom water circulation at the depth of Site 1233 (Antarctic Intermediate Water; e.g., (Shaffer et al., 2004)) is rather too sluggish for the re-suspension of sediments and internal waves have not been described at the Chilean margin. We suggest that the constant admixture of older material that would affect the ${ }^{14} \mathrm{C}$ ages of the alkenone fraction but not significantly the reconstructed alkenone temperatures would be likewise conceivable, a possibility that Mollenhauer et al. (2005) did not exclude either. We therefore assume that our SST record is not substantially affected by any age offsets between the alkenone containing fine fraction and the coarse fraction foraminifera that have been used for dating in our study.

\subsection{Modelling}

The transient glacial-interglacial simulation shown in Fig. 5H was performed with the ECBilt-Clio climate model and includes the time-varying orographic and albedo ice-sheet effects, greenhouse gas changes, and orbital forcing variations. The time-varying greenhouse gas forcing uses $\mathrm{CO}_{2}, \mathrm{CH}_{4}$, and $\mathrm{N}_{2} \mathrm{O}$ concentrations. Concentration values were measured on the Antarctica ice-core Taylor Dome (Indermühle et al., 2000; Smith et al., 1999). The time-scale was aligned to the GISP2 time-scale (Meese et al., 1997). $\mathrm{CH}_{4}$ and $\mathrm{N}_{2} \mathrm{O}$ were measured in samples from the GISP2 ice-core (Sowers et al., 2003). The most relevant greenhouse gas changes are associated with $\mathrm{CO}_{2}$. During the LGM the estimated global radiative forcing anomaly with respect to pre-industrial conditions amounts to about $-2 \mathrm{~W} / \mathrm{m}^{2}$ (compared to $-0.22 \mathrm{~W} / \mathrm{m}^{2}$ and $-0.25 \mathrm{~W} / \mathrm{m}^{2}$ for $\mathrm{CH}_{4}$ and $\mathrm{N}_{2} \mathrm{O}$, respectively).

\section{Results and discussion}

\subsection{Sea surface temperatures off Chile compared to Antarctic ice-core records}

Deglacial warming in our alkenone SST record starts at $\sim 18.8 \mathrm{kyr}$ BP with a $\sim 2$-kyr-long increase of nearly $5{ }^{\circ} \mathrm{C}$ until $\sim 16.7$ kyr BP (Fig. 4A). Thereafter, temperatures remain comparatively stable until the beginning of a second warming step of $\sim 2{ }^{\circ} \mathrm{C}$ between $\sim 12.7$ and $\sim 12.1$ kyr BP. A comparison of our SST record to different Antarctic ice-core records suggests a general correspondence in the major temperature trends, particularly the two-step warming over T1. As in our SST record, in the Pacific Sector of Antarctica, (Byrd, Fig. 4B) (Blunier and Brook, 2001), deglacial warming initiated shortly after $19 \mathrm{kyr}$ BP. Both records show very similar millennial-scale variations before T1 though these changes partly reveal larger offsets in particular between $\sim 19$ and $23 \mathrm{kyr}$ BP where the methane synchronization is uncertain (Blunier and Brook, 2001; Epica Community Members, 2006) (i.e., the SST minimum close to $22.5 \mathrm{kyr}$ BP may well correspond to the temperature minimum at $\sim 21.5 \mathrm{kyr} \mathrm{BP}$ in the Byrd record). The new record from Dronning Maud Land (Epica Community Members, 2006) (DML; Atlantic Sector; Fig. 4C), shows a $\sim 600$-year delayed initiation of deglacial warming and a millennial-scale warming between $\sim 23.5$ and $24.5 \mathrm{kyr}$ BP (Antarctic Isotope 


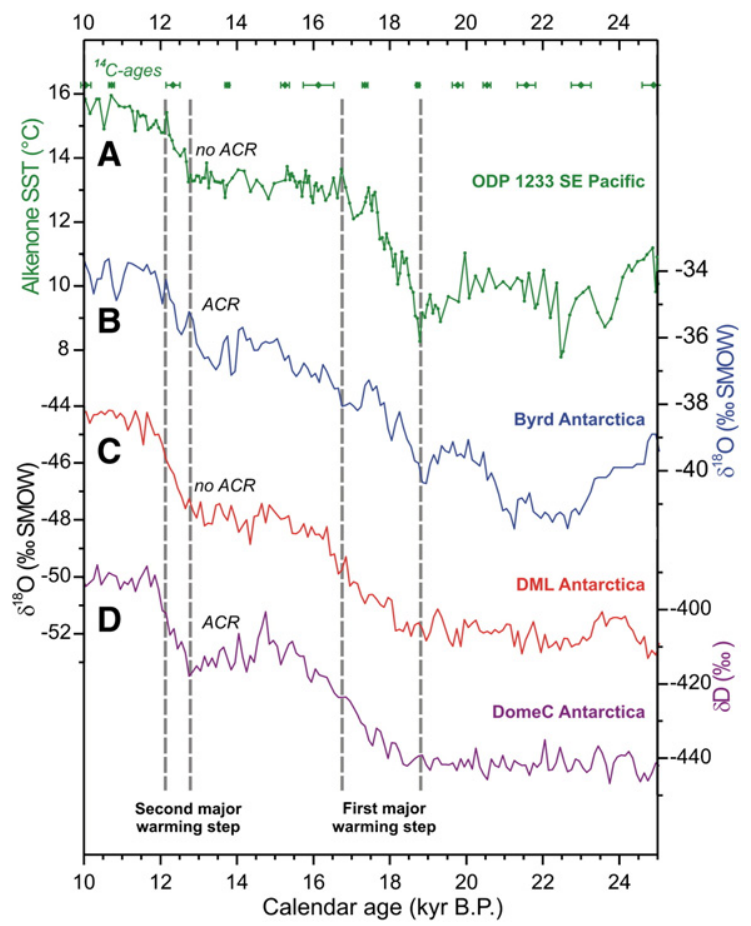

Fig. 4. Southeast Pacific SST record compared to different Antarctic temperature proxy records over T1. (A) Alkenone SST record from Site 1233 with radiocarbon datings (this study). (B) Oxygen isotope record from the Byrd ice-core (Blunier and Brook, 2001) (coastal site, Pacific sector). (C) Oxygen isotope record from the Dronning Maud Land (DML) ice-core (Epica Community Members, 2006) (coastal site, Atlantic sector). (D) Deuterium record from the Dome C ice-core (Epica Community Members, 2004) (continental site in eastern Antarctica). All ice-core records are plotted on the GICC05 displaying 100-year averages.

Maximum 2) that occurs $\sim 500$ years later than a warming shown in the SST data. In the Dome $\mathrm{C}$ record (Epica Community Members, 2004) (continental site, Fig. 4D), the initial warming starts at about the same time as in the DML record. In general, the deglacial warming as documented in Antarctic ice-cores is substantially more gradual than observed in our SST record where most of the initial warming occurs over a time-interval of only $\sim 1200$ years $(\sim 18.8$ to $17.6 \mathrm{kyr} \mathrm{BP})$.

\subsection{The bipolar seesaw}

Millennial-scale temperature changes in Antarctica over the last glacial may be consistently explained by the bipolar seesaw concept that suggests an out-of-phase millennial-scale climate pattern between the $\mathrm{NH}$ and $\mathrm{SH}$ during the last glacial (e.g., Stocker et al., 1998). The concept was later extended by including a time constant that describes the thermal storage effect of the Southern Ocean and explains why glacial Antarctic and Greenland temperatures are not strictly anti-correlated but are rather characterised by a lead-lag relationship (Knutti et al., 2004; Siddall et al., 2006; Stocker and Johnsen, 2003)). Over T1, the bipolar seesaw concept and its interference with orbital-scale changes in different components of the climate system has been much less investigated (Clark et al., 2002). The initiation of deglacial warming in the SE-Pacific shortly after 19 kyr BP coincides very closely with a starting slowdown of the Atlantic meridional overturning circulation (AMOC) (McManus et al., 2004) (Fig. 5B) and a beginning NH (Greenland) cooling towards HE 1 (Fig. 5C). The freshwater input that started the reduction of the AMOC likely originated from the beginning deglaciation of the NH ice sheets. This is shown for example by a recent study on changes in the extension of the Scandinavian Ice Sheet over T1 (Rinterknecht et al., 2006) (Fig. 5A) suggesting that deglaciation began at $\sim 19$ kyr BP synchronous with a previously suggested sea-level rise in the order of 10 to $15 \mathrm{~m}$ (Clark et al., 2004). The related freshwater input was later reinforced during subsequent HE 1 (Clark et al., 2004; Rinterknecht et al., 2006). By inducing Antarctic ice-sheet melting, the SH warming may then have fed back to the NH by resuming the AMOC leading into the $\mathrm{B} / \mathrm{A}$ warm period as indicated by modelling studies (Knorr and Lohmann, 2003; Weaver et al., 2003). During this time interval, $\mathrm{SH}$ warming slowed down or even reversed (ACR). Both our record and the Antarctic icecore data reveal that the second reduction of the AMOC again reinforced the $\mathrm{SH}$ warming as documented in the second major warming step during the $\mathrm{NH}$ YD cold phase (Fig. 5).

The timing of both the initial and the second warming step in our data, suggests that the SST response in the mid-latitude SE-Pacific occurred quasi instantaneous to the starting slowdown of the AMOC (Fig. 5). The conceptual model of Stocker and Johnsen (2003) shows such strict antiphase behaviour for the South Atlantic. However, the occurrence of an "immediate" and high amplitude response in our SST record requires a rapid transfer of the Atlantic signal to the SE-Pacific without involving the thermal inertia of the Southern Ocean that contributed to the substantially more gradual and partly delayed (in case of the DML and Dome C records) deglacial temperature rise seen in Antarctic ice-cores. The most plausible mechanism for this rapid transfer is a seesaw-induced change of the coupled ocean-atmosphere system of the ACC and the southern westerly wind belt. Using a coupled atmosphere-ocean-sea ice model, Timmermann et al. (2005) show a substantial decrease of westerly airflow between $\sim 40$ and $\sim 50^{\circ} \mathrm{S}$ and an increase further south in the South Pacific for an 
AMOC shutdown experiment compared to a Last Glacial Maximum simulation (Fig. 6). This latitudinal shift of the SH westerlies is a robust feature in a number North Atlantic water-hosing experiments with Coupled General Circulation Models (Timmermann et al., in press).

\subsection{Other forcings beyond the bipolar seesaw}

The SST response to a weakening of the AMOC in these and other model simulations (e.g., Knutti et al., 2004; Schmittner et al., 2002) is, however, much smaller

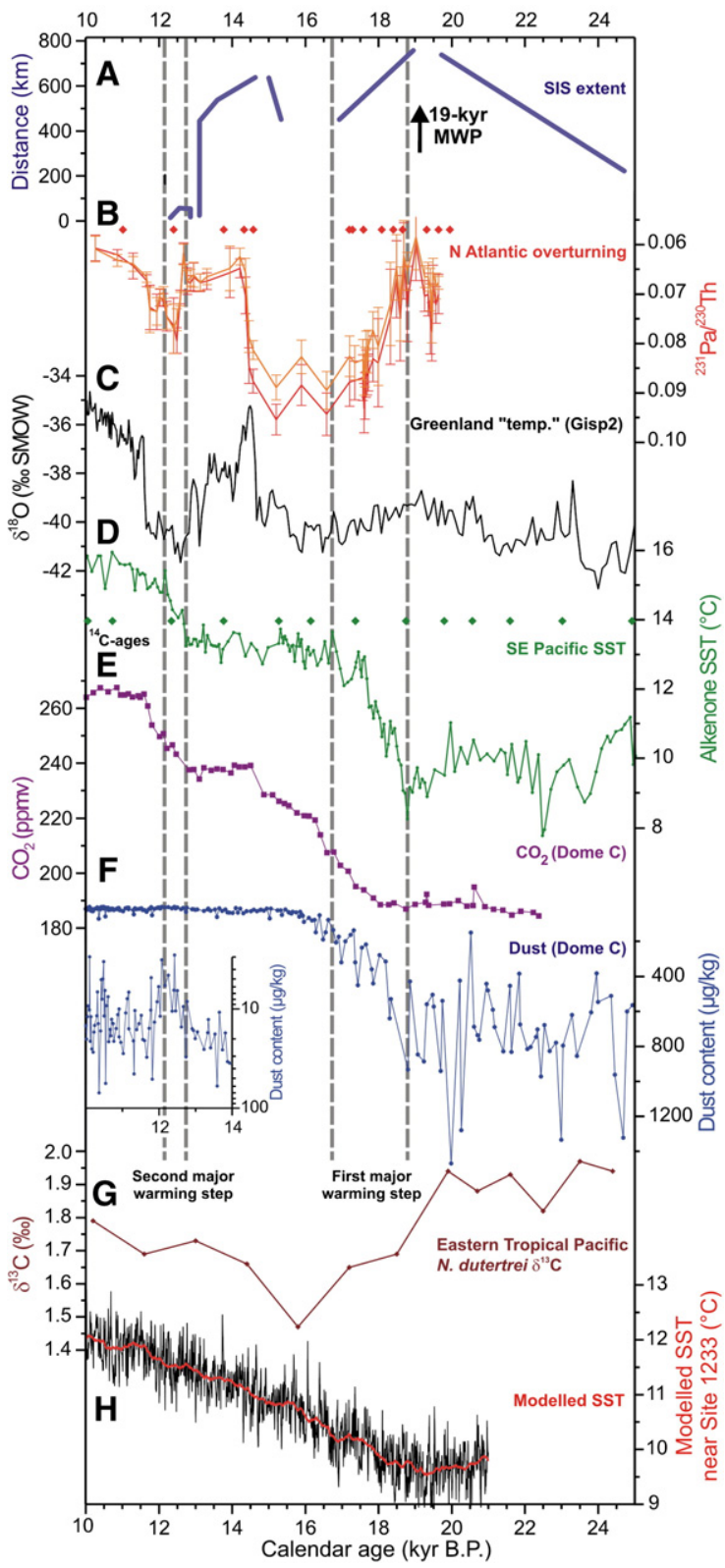

than the initial warming observed at Site 1233 (Fig. 6). Part of the high amplitude SST response at our Pacific site is likely caused by the very pronounced regional SST gradients (Fig. 1). These gradients are intimately linked to the northern margin of the westerlies and the ACC and provide a regional sensitivity that may not be captured by the comparatively coarse climate models. Moreover, in contrast to the glacial period, bipolar seesaw induced climate variations over $\mathrm{T} 1$ are more strongly superimposed by changes in important forcing factors such as insolation and atmospheric $\mathrm{CO}_{2}$ content. A transient glacial-interglacial simulation with the ECBilt-Clio climate model which neglects late glacial millennial-scale meltwater forcing, suggests a substantial SST rise in the SE-Pacific that likewise starts at $\sim 19$ kyr BP (Fig. 5H). In this transient simulation, the SE-Pacific temperature response to orbital and greenhouse gas forcing shows a more gradual increase in contrast to the distinct two-step warming observed in our record. This further strengthens the importance of the superposition of seesaw related processes with other forcings such as orbitally induced seasonal variations of incoming solar radiation and atmospheric $\mathrm{CO}_{2}$ that were unique to $\mathrm{T} 1$.

An additional warming not considered in most climate models may also be related to substantially decreasing atmospheric dust contents as recorded in Antarctic ice-cores. Dust contents in Antarctic ice decrease notably to already Holocene levels during the first major warming step recorded in our SST record (Fig. 5F). A minor decrease observed in the log-scaled record (Fig. 5F) also occurs over the second major warming step. Antarctic dust primarily originates from Southern Patagonia and its content in the ice is controlled

Fig. 5. Compilation of paleoclimatic records to explain interhemispheric climate pattern over T1. (A) Time-distance diagram of fluctuations of the southern Scandinavian ice-sheet (SIS) margin (Rinterknecht et al., 2006) including the position of the 19-kyr sealevel rise after Clark et al. (2004). (B) ${ }^{231} \mathrm{~Pa} /{ }^{230} \mathrm{Th}$ record from a subtropical North Atlantic sediment core with radiocarbon datings taken as a proxy for the strength of the Atlantic meridional overturning circulation (McManus et al., 2004). (C) Oxygen isotope record of the Gisp2 ice-core, Greenland (Grootes et al., 1993). (D) Alkenone SST record from Site 1233 with radiocarbon datings. (E) $\mathrm{CO}_{2}$ record from the Dome C ice-core (Monnin et al., 2001) (methane-synchronized to the GICC05). (F) Atmospheric dust content record from the Dome C ice-core (Delmonte et al., 2002) (on the GICC05). Small insert figure shows dust record on log-scale for the interval 10-14 kyr BP. (G) Carbon isotope record from Site TR163-19, eastern equatorial Pacific (Spero and Lea, 2002). (H) Modelled SST record at Site 1233 conducted with a transient glacial-interglacial simulation (ECBiltClio) including orographic and albedo ice-sheet effects, $\mathrm{CO}_{2}$ changes, and orbital forcing. 


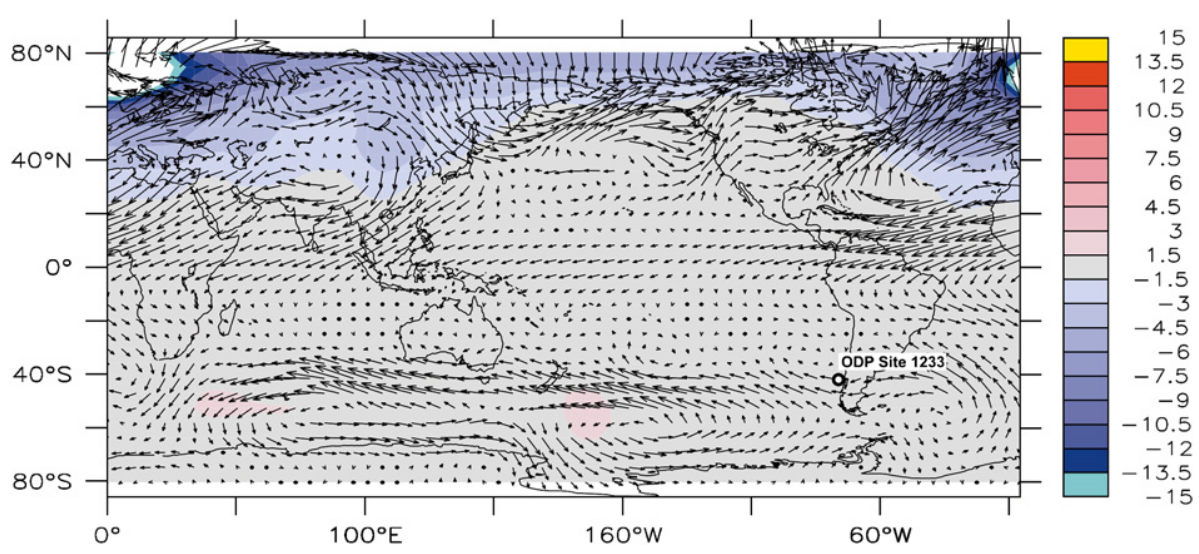

Fig. 6. Atmospheric response to a transient glacial meltwater experiment leading to a complete shutdown of the AMOC performed with the ECBiltClio climate model (Timmermann et al., 2005). Shown is the difference of time-averaged wind stress (vectors, eastward direction means decrease of westerly airflow) and temperature (shading) fields between the meltwater experiment and a Last Glacial Maximum simulation. This situation represents the response to the slowdown of the AMOC beginning at $\sim 19 \mathrm{kyr}$ BP as seen in the proxy records (Fig. 4). Note the decrease of westerly airflow in the Southern Hemisphere mid-latitudes and increase in the Southern Ocean consistent with a latitudinal shift of the westerly wind belt. The temperature response is, however, only minor.

by atmospheric circulation pattern over Patagonia and the Southern Ocean in addition to impacts of regional aridity and sea level (Delmonte et al., 2002; Wolff et al., 2006). Though the climatic impact of regional atmospheric dust content changes are discussed controversially (Harrison et al., 2001), a slight warming in the order of 0.5 to $1{ }^{\circ} \mathrm{C}$ in the $\mathrm{SH}$ mid and high latitudes in response to decreasing atmospheric dust content levels over $\mathrm{T} 1$ as indicated by climate models (Schneider von Deimling et al., 2006) can not be excluded.

\subsection{Southeast Pacific SSTs and atmospheric $\mathrm{CO}_{2}$}

A two-step pattern as in our SST record is also apparent in the $\mathrm{CO}_{2}$ record from the Dome $\mathrm{C}$ ice-core (Monnin et al., 2001) that, however, results in the model simulation only in a gradual warming (Fig. $5 \mathrm{H}$ ). The correspondence of the deglacial pattern in SE-Pacific SST and the $\mathrm{CO}_{2}$ record is remarkable. The initial warming $\left(\sim 5^{\circ} \mathrm{C}\right)$ in our SST record slightly predates $(\sim 700$ years $)$ the most significant increase in $\mathrm{CO}_{2}$ $(\sim 35$ ppmv, interval $\mathrm{I}$ in Monnin et al. (2001)). The second major warming step during the $\mathrm{NH} Y \mathrm{YD}\left(\sim 2{ }^{\circ} \mathrm{C}\right)$ in our SST record coincides with another $\mathrm{CO}_{2}$ increase of $\sim 15$ ppmv (first part of interval IV in Monnin et al. (2001)) (Fig. 5D-E). Assuming that our record largely reflects shifts of the coupled ACC/westerlies system, this concurrence is consistent with the previously suggested important role of such latitudinal shifts in controlling atmospheric $\mathrm{CO}_{2}$ contents (Ninnemann and Charles, 1997; Toggweiler et al., 2006). Based on a general circulation model, Toggweiler et al. (2006) showed that the equatorward shifted $\mathrm{SH}$ westerlies during the glacial allowed more respired $\mathrm{CO}_{2}$ to accumulate in the deep ocean. During glacial terminations, the southward moving westerlies reduced polar stratification and enhanced upwelling of deepwater masses around Antarctica that would then have released large amounts of the stored $\mathrm{CO}_{2}$ to the atmosphere. Such a mechanism is supported by the occurrence of a pronounced $\delta{ }^{13} \mathrm{C}$ minimum recorded in thermoclinedwelling foraminifera in the equatorial Pacific (Spero and Lea, 2002). Within dating uncertainties, the onset of this event during T1 coincides with the initiation of SST warming and beginning southward movement of the westerlies (Fig. 5G) and has been interpreted in terms of a breakdown of surface water stratification and renewed Circumpolar Deep Water upwelling in the Southern Ocean (Spero and Lea, 2002). The $\sim 700$-year delayed beginning of the initial $\mathrm{CO}_{2}$ rise compared to the SE-Pacific SST rise is probably related to the uncertain methane synchronization during the beginning deglaciation (Fig. 3). This interpretation is supported by the exact beginning of the second step during the YD when the synchronization is very accurate. In addition, new constraints on the gas ageice age difference along the Epica ice-cores suggest that the lag of the $\mathrm{CO}_{2}$ increase at the start of $\mathrm{T} 1$ as proposed by Monnin et al. (2001) is overestimated and that the $\mathrm{CO}_{2}$ increase could well have been in phase or slightly leading the temperature increase at Dome $\mathrm{C}$ (Loulergue et al., 2007). This would move the initiation of the $\mathrm{CO}_{2}$ rise close to the observed warming at our site. 
We observe a similar link between SE-Pacific SSTs and $\mathrm{CO}_{2}$ for older intervals, for example the transition from marine isotope stage (MIS) 4 to MIS 3, though in this case a slightly lower $\mathrm{CO}_{2}$ increase of $\sim 25 \mathrm{ppmv}$ corresponds to a $\sim 5^{\circ} \mathrm{C} \mathrm{SST}$ increase (Fig. $7 \mathrm{~B}-\mathrm{C}$ ). An important question is why the partly substantial glacial SST changes in the SE-Pacific and the associated shifts of the $\mathrm{SH}$ westerlies and ACC system that resulted sometimes in nearly similar $\mathrm{CO}_{2}$ changes as over the first deglacial warming step have not initiated interglacial conditions? One answer may be related to the duration of the preceding cold phase. It is well conceivable that larger amounts of $\mathrm{CO}_{2}$ were stored in the deep ocean during the long-lasting glacial phase with low $\mathrm{CO}_{2}$ contents of late MIS 3 and MIS 2 compared to the comparatively short MIS 4 that was preceded by nearly interglacial conditions during late MIS 5. Thus, even during comparable insolation changes, the release of $\mathrm{CO}_{2}$ from the deep-water reservoir at $\mathrm{T} 1$ is expected to

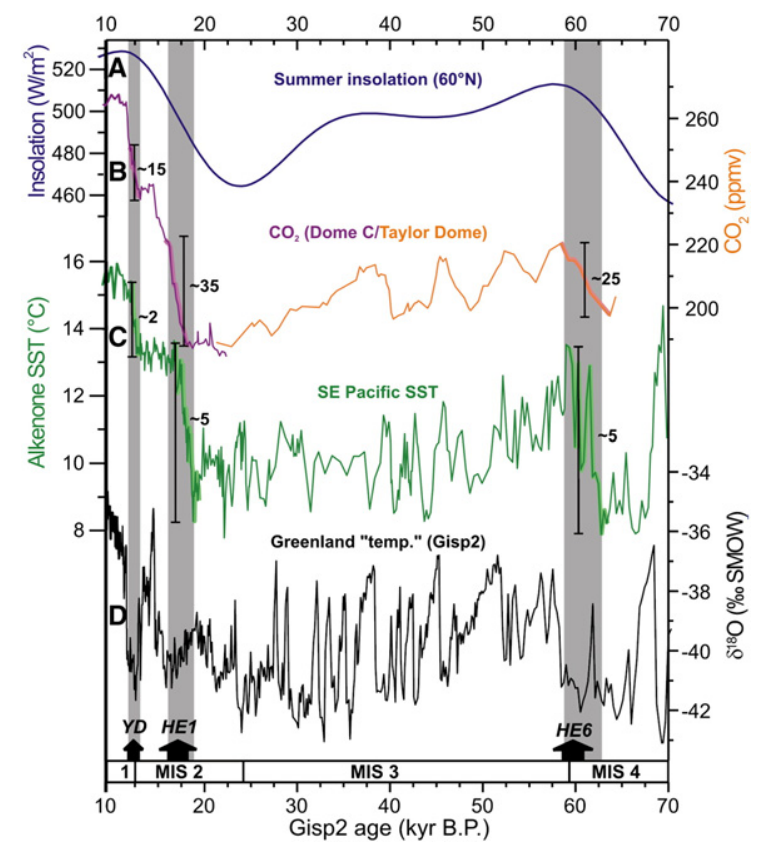

Fig. 7. Comparison of Southeast Pacific SST and atmospheric $\mathrm{CO}_{2}$ records over T1 to the transition from MIS 4 to MIS 3. (A) Summer insolation at $60^{\circ} \mathrm{N}$ (Berger and Loutre, 1991). (B) $\mathrm{CO}_{2}$ record from the Dome C (Monnin et al., 2001) (methane-synchronized to the GICC05) and Taylor Dome ice-cores (Indermühle et al., 2000). The time-scale of the Taylor Dome record has been adapted to the Gisp2-synchronized age model of the Byrd ice-core (Blunier and Brook, 2001). (C) Alkenone SST record from Site 1233 over the past $70 \mathrm{kyr}$ (this study and Kaiser et al., 2005) plotted on the time-scale as published in Kaiser et al. (2005). (D) Oxygen isotope record of the Gisp2 ice-core, Greenland (Grootes et al., 1993). Intervals of substantial SST warming and $\mathrm{CO}_{2}$ increase over $\mathrm{T} 1$ and at the MIS4/3 transition are marked. Numbers show approximate amplitude in ppmv and ${ }^{\circ} \mathrm{C}$. have been larger. Probably more important is the particular combination of orbital-scale insolation changes and millennial-scale climate variability over $\mathrm{T} 1 . \mathrm{NH}$ summer insolation similarly increased at the MIS $4 / 3$ transition (Fig. 7A) and a major slowdown of the AMOC (HE 6) likewise occurred during this interval (Fig. 7D). However, the Toggweiler et al. (2006) model suggests that the system may be characterised by a threshold beyond that the westerlies and $\mathrm{CO}_{2}$ level would rapidly move towards either their glacial or interglacial positions. It is well conceivable that this threshold was not reached at the transition from MIS 4 to MIS 3 because only one single major slowdown in the AMOC (i.e., HE 6) occurred late in the interval of increasing $\mathrm{NH}$ summer insolation. Over $\mathrm{T} 1$, the beginning slowdown of the AMOC towards HE 1 took place early in the interval of insolation increase and was followed by a second slowdown (the YD) only a few millennia later (Fig. 7). Taken together, both episodes likely moved the climate system into interglacial conditions. The intervening resumption of the AMOC during the B/A was apparently insufficient to move the westerlies significantly back north as shown by the longer SST "plateau" lasting from $\sim 16.7$ to $\sim 12.7$ kyr BP. Consistent with an interrupted rather than reversed SH warming and southward movement of the westerlies, the $\mathrm{CO}_{2}$ record of Dome $\mathrm{C}$ shows constant values over the ACR (Fig. 5E). Furthermore, a clear cooling during the ACR is likewise missing in the DML ice-core record (Fig. 4C) but particularly well developed in the more continental drilling sites as Dome C (Fig. 4D) and Vostok (not shown on Fig. 4).

\section{Conclusions}

Our SE-Pacific SST record provides a unique opportunity to discuss globally relevant processes over Termination 1 on an absolute radiocarbon-based time-scale. This point is particularly important as the lack of reliable dating accuracy often hampered the exact dating of the onset of deglacial warming in the Southern Ocean (due to large and variable reservoir ages). Furthermore, Antarctic ice core records cannot be unambiguously synchronized to the Northern Hemisphere because of only minor methane fluctuation during this particular interval.

Deglacial warming at the northern margin of the Antarctic Circumpolar Current system (ACC) began shortly after $19 \mathrm{kyr}$ BP. Though this timing is largely consistent with Antarctic ice-core records, the initial warming in the SE-Pacific is more abrupt suggesting a direct and immediate response to the slowdown of the Atlantic thermohaline circulation through the bipolar seesaw mechanism. This response requires a rapid tran- 
sfer of the Atlantic signal to the SE-Pacific without involving the thermal inertia of the Southern Ocean that may contribute to the substantially more gradual deglacial temperature rise seen in Antarctic ice-cores. The most plausible mechanism for this rapid transfer is a seesaw induced change of the coupled ocean-atmosphere system of the ACC and the southern westerly wind belt as supported by North Atlantic water-hosing model experiments. The observed SST warming can however not be explained by the bipolar seesaw alone. Our modelling results suggest that a substantial part of the signal is induced by insolation changes and the deglacial $\mathrm{CO}_{2}$ rise that are superimposed on the bipolar seesaw-induced signal but only lead to a gradual warming at our site.

The similarity of the two-step rise in our proxy SSTs and $\mathrm{CO}_{2}$ over $\mathrm{T} 1$ strongly demands for a forcing mechanism influencing both, temperature and $\mathrm{CO}_{2}$. As SSTs at our coring site are particularly sensitive to latitudinal shifts of the ACC/southern westerly wind belt system, we conclude that such latitudinal shifts may substantially affect the upwelling of deepwater masses in the Southern Ocean and thus the release of $\mathrm{CO}_{2}$ to the atmosphere as suggested by the conceptual model of Toggweiler et al. (2006). This connection of atmospheric $\mathrm{CO}_{2}$ contents to SST changes in the Southeast Pacific and the position of the westerlies may be very relevant for our future climate as some models see significant shifts of the westerlies under future greenhouse scenarios (e.g., Yin, 2005).

An often discussed but still not resolved question is the role of the tropics, in particular of the tropical Pacific. Recent SST reconstructions from the Indo-Pacific Warm Pool (Visser et al., 2003) and the eastern tropical Pacific (Lea et al., 2006) show some similarities with our SST record but with generally much smaller amplitudes. This may well be explained by a transmission of South Pacific SST warming through the surface ocean via the Eastern Boundary Current system and through intermediate water masses towards the tropics (Clark et al., 2004). Such SST changes in the tropical Pacific may have introduced important feedbacks by their large impact on the hydrological cycle and the greenhouse gas concentration (Clark et al., 2004; Palmer and Pearson, 2003).

\section{Acknowledgments}

We thank P. Clark, A. Ganopolski, A. Mix, A. Schmittner, B. Stenni, T. Stocker, J. Stoner, B. Weninger, and R. Tiedemann for comments and suggestions as well as T. Blunier, H. Fischer, and J. McManus for data. The constructive reviews by M. Siddall and two anonymous reviewers improved this paper. Financial support was made available through the Deutsche Forschungsgemeinschaft (DFG). This research used samples provided by the Ocean Drilling Program (ODP). The ODP is sponsored by the U.S. National Science Foundation (NSF) and participating countries under management of Joint Oceanographic Institutions (JOI), Inc.

\section{References}

Alley, R.B., Clark, P.U., 1999. The deglaciation of the Northern Hemisphere. Annu. Rev. Earth Planet. Sci. 27, 149-182.

Alley, R.B., Brook, E.J., Anandakrishnan, S., 2002. A northern lead in the orbital band: North-south phasing of Ice-Age events. Quat. Sci. Rev. 21, 431-441.

Andersen, K.K., Svensson, A., Johnsen, S.J., Rasmussen, S.O., Bigler, M., Rothlisberger, R., Ruth, U., Siggaard-Andersen, M.-L., Peder Steffensen, J., Dahl-Jensen, D., Vinther, B.M., Clausen, H.B., 2006. The Greenland Ice Core Chronology 2005, 15-42 ka. Part 1: constructing the time scale. Quat. Sci. Rev. 25, 3246-3257.

Bard, E., Rostek, F., Sonzogni, C., 1997. Interhemispheric sychrony of the last deglaciation inferred from alkenone palaeothermometry. Nature 385, 707-710.

Berger, A., Loutre, M.F., 1991. Insolation values for the climate of the last 10 million years. Quat. Sci. Rev. 10, 297-317.

Bianchi, C., Gersonde, R., 2004. Climate evolution at the last deglaciation: The role of the Southern Ocean. Earth Planet. Sci. Lett. 228, 407-424.

Blunier, T., Brook, E.J., 2001. Timing of millennial-scale climate change in Antarctica and Greenland during the last glacial period. Science 291, 109-112.

Blunier, T., Spahni, R., Barnola, J.M., Chappellaz, J., Loulergue, L., Schwander, J., 2007. Synchronization of ice core records via atmospheric gases. Clim. Past Discuss. 3, 365-381.

Clark, P.U., Alley, R.B., Pollard, D., 1999. Northern Hemisphere icesheet influences on global climate change. Science 286, 1104-1111.

Clark, P.U., Pisias, N.G., Stocker, T.F., Weaver, A.J., 2002. The role of the thermohaline circulation in abrupt climate change. Nature 415 , 863-869.

Clark, P.U., McCabe, A.M., Mix, A.C., Weaver, A.J., 2004. Rapid rise of sea level 19,000 years ago and its global implications. Science 304, 1141-1144.

Delmonte, B., Petit, J., Maggi, V., 2002. Glacial to Holocene implications of the new 27000-year dust record from the EPICA Dome C (East Antarctica) ice core. Clim. Dyn. 18, 647-660.

Epica Community Members, 2004. Eight glacial cycles from an Antarctic ice core. Nature 429, 623-628.

Epica Community Members, 2006. One-to-one coupling of glacial climate variability in Greenland and Antarctica. Nature 444, 195-198.

Fairbanks, R.G., Mortlocka, R.A., Chiua, T.-C., Caoa, L., Kaplana, A., Guilderson, T.P., Fairbanks, T.W., Bloom, A.L., Grootes, P.M., Nadeau, M.-J., 2005. Radiocarbon calibration curve spanning 0 to 50,000 years BP based on paired $230 \mathrm{Th} / 234 \mathrm{U} / 238 \mathrm{U}$ and ${ }^{14} \mathrm{C}$ dates on pristine corals. Quat. Sci. Rev. 24, 1781-1796.

Grootes, P.M., Stuiver, M., White, J.W.C., Johnsen, S., Jouzel, J., 1993. Comparision of oxygen isotope records from the GISP2 and GRIP Greenland ice cores. Nature 366, 552-554.

Harrison, S.P., Kohfeld, K.E., Roelandt, C., Claquin, T., 2001. The role of dust in climate changes today, at the last glacial maximum and in the future. Earth-Sci. Rev. 54, 43-80. 
Hughen, K., Lehman, S., Southon, J., Overpeck, J., Marchal, O., Herring, C., Turnbull, J., 2004. C-14 activity and global carbon cycle changes over the past 50,000 years. Science 303, 202-207.

Indermühle, A., Monnin, E., Stauffer, B., Stocker, T.F., Wahlen, M., 2000. Atmospheric $\mathrm{CO}_{2}$ concentration from 60 to $20 \mathrm{kyr} \mathrm{BP}$ from the Taylor Dome ice core, Antarctica. Geophys. Res. Lett. 27, 735-738

Kaiser, J., Lamy, F., Hebbeln, D., 2005. A 70-kyr sea surface temperature record off southern Chile (ODP Site 1233). Paleoceanography 20, PA4009. doi:10.1029/2005PA001146.

Kim, J.H., Schneider, R.R., Hebbeln, D., Muller, P.J., Wefer, G., 2002. Last deglacial sea-surface temperature evolution in the Southeast Pacific compared to climate changes on the South American continent. Quat. Sci. Rev. 21, 2085-2097.

Knorr, G., Lohmann, G., 2003. Southern Ocean origin for the resumption of Atlantic thermohaline circulation during deglaciation. Nature 424, 532-536.

Knutti, R., Flückiger, J., Stocker, T., Timmermann, A., 2004. Strong hemispheric coupling of glacial climate through freshwater discharge and ocean circulation. Nature 430, 851-856.

Lamy, F., Hebbeln, D., Rohl, U., Wefer, G., 2001. Holocene rainfall variability in southern Chile: a marine record of latitudinal shifts of the Southern Westerlies. Earth Planet. Sci. Lett. 185, 369-382.

Lamy, F., Kaiser, J., Ninnemann, U., Hebbeln, D., Arz, H., Stoner, J., 2004. Antarctic Timing of Surface Water Changes off Chile and Patagonian Ice Sheet Response. Science 304, 1959-1962.

Lea, D.W., Pak, D.K., Belanger, C.L., Spero, H.J., Hall, M.A., Shackleton, N.J., 2006. Paleoclimate history of Galápagos surface waters over the last 135,000 yr. Quat. Sci. Rev. 25, 1152-1167.

Loulergue, L., Parrenin, F., Blunier, T., Barnola, J.-M., Spahni, R., Schilt, R., Raisbeck, G., Chappellaz, J., 2007. New constraints on the gas age-ice age difference along the EPICA ice cores, $0-50 \mathrm{kyr}$. Clim. Past Discuss 3, 435-467.

Martinez, P., Lamy, F., Robinson, R.R., Pichevin, L., Billy, I., 2006. Atypical $\mathrm{d} 15 \mathrm{~N}$ variations at the southern boundary of the East Pacific oxygen minimum zone over the last $50 \mathrm{ka}$. Quat. Sci. Rev. 25, 3017-3028.

McManus, J., Francois, R., Gherardi, J.-M., Kelgwin, L.D., BrownLeger, S., 2004. Collapse and rapid resumption of Atlantic meridional circulation linked to deglacial climate changes. Nature 428, 834-837.

Meese, D.A., Gow, A.J., Alley, R.B., Zielinski, G.A., Grootes, P.M., Ram, P.M., Taylor, K.C., Mayewski, P.A., Bolzan, J.F., 1997. The Greenland Ice Sheet Project 2 depth-age scale: Methods and results. J. Geophys. Res. 102, 26411-26423.

Mix, A.C., Tiedemann, R., Blum, P., Scientists, S., 2003. Southeast Pacific paleoceanographic transects. Ocean Drill. Program. Proc. ODP, Initial Reports, vol. 202, 145 pp.

Mollenhauer, G., Kienast, M., Lamy, F., Meggers, H., Schneider, R.R., Hayes, J.M., Eglinton, T.I., 2005. An evaluation of C-14 age relationships between co-occurring foraminifera, alkenones, and total organic carbon in continental margin sediments. Paleoceanography 20 .

Monnin, E., Indermühle, A., Dallenbach, A., Fluckiger, J., Stauffer, B., Stocker, T.F., Raynaud, D., Barnola, J.M., 2001. Atmospheric CO2 concentrations over the last glacial termination. Science 291, $112-114$

Morgan, V., Delmotte, M., van, O.T., Jouzel, J., Chappellaz, J., Woon, S., Masson, D.V., Raynaud, D., 2002. Relative timing of deglacial climate events in Antarctica and Greenland. Science 297, 1862-1864.
Müller, P.J., Kirst, G., Ruhland, G., von Storch, I., Rosell-Mele, A., 1998. Calibration of the alkenone paleotemperature index UK'37 based on core-tops from the eastern South Atlantic and the global ocean $(60$ (N-60(S). Geochim. Cosmochim. Acta 62, 1757-1772.

Ninnemann, U.S., Charles, C.D., 1997. Regional differences in Quaternary Subantarctic nutrient cycling: Link to intermediate and deep water ventilation. Paleoceanography 12, 560-567.

Pahnke, K., Zahn, R., Elderfield, H., Schulz, M., 2003. 340,000-year centennial-scale marine record of Southern Hemisphere climatic oscillation. Science 301, 948-952.

Palmer, M.R., Pearson, P.N., 2003. A 23,000-year record of surface water $\mathrm{pH}$ and $\mathrm{PCO} 2$ in the western Equatorial Pacific ocean. Science 300, 480-482.

Prahl, F.G., Muehhausen, L.A., Zahnle, D.L., 1988. Further evaluation of long-chain alkenones as indicators of paleoceanographic conditions. Geochim. Cosmochim. Acta 52, 2303-2310.

Reimer, P.J., Baillie, M.G.L., Bard, E., Bayliss, A., Beck, J.W., Bertrand, C.J.H., Blackwell, P.G., Buck, C.E., Burr, G.S., Cutler, K.B., Damon, P.E., Edwards, R.L., Fairbanks, R.G., Friedrich, M., Guilderson, T.P., Hogg, A.G., Hughen, K.A., Kromer, B., McCormac, F.G., Manning, S.W., Ramsey, C.B., Reimer, R.W., Remmele, S., Southon, J.R., Stuiver, M., Talamo, S., Taylor, F.W., van der Plicht, J., Weyhenmeyer, C.E., 2004. IntCal04 terrestrial radiocarbon age calibration, 26-0 ka BP. Radiocarbon 46, $1029-1058$.

Rinterknecht, V.R., Clark, P.U., Raisbeck, G.M., Yiou, F., Bitinas, A., Brook, E.J., Marks, L., Zelcs, V., Lunkka, J.P., Pavlovskaya, I.E., Piotrowski, J.A., Raukas, A., 2006. The Last Deglaciation of the Southeastern Sector of the Scandinavian Ice Sheet. Science 311, $1449-1452$.

Robinson, L.F., Adkins, J.F., Keigwin, L.D., Southon, J., Fernandez, D.P., Wang, S.L., Scheirer, D.S., 2005. Radiocarbon variability in the western North Atlantic during the last deglaciation. Science 310, 1469-1473.

Sarnthein, M., Kiefer, T., Grootes, P.M., Elderfield, H., Erlenkeuser, H., 2006. Warmings in the far northwestern Pacific promoted preClovis immigration to America during Heinrich event 1. Geology 34, 141-144.

Schmittner, A., Yoshimori, M., Weaver, A.J., 2002. Instability of Glacial Climate in a Model of the Ocean- Atmosphere-Cryosphere System. Science 295, 1489-1493.

Schneider von Deimling, T., Ganopolski, A., Held, H., Rahmstorf, S., 2006. How cold was the Last Glacial Maximum? Geophys. Res. Lett. 33.

Shackleton, N.J., Fairbanks, R.G., Chiu, T.-c., Parrenin, F., 2004. Absolute calibration of the Greenland time scale: implications for Antarctic time scales and for $[$ Delta $]{ }^{14}$ C. Quat. Sci. Rev. 23, $1513-1522$.

Shaffer, G., Hormazabal, S., Pizarro, O., Ramos, M., 2004. Circulation and variability in the Chile Basin. Deep-Sea Res., Part I, Oceanogr. Res. Pap. 51, 1367-1386.

Shemesh, A., Hodell, D., Crosta, X., Kanfoush, S., Charles, C., Guilderson, T., 2002. Sequence of events during the last deglaciation in Southern Ocean sediments and Antarctic ice cores. Paleoceanography 17, 1056. doi:1010.1029/2000PA00599.

Siddall, M., Stocker, T.F., Blunier, T., Spahni, R., McManus, J.F., Bard, E., 2006. Using a maximum simplicity paleoclimate model to simulate millennial variability during the last four glacial cycles. Quat. Sci. Rev. 25, 3185-3197.

Smith, H.J., Fischer, H., Wahlen, M., Mastroianni, D., Deck, B., 1999. Dual modes of the carbon cycle since the Last Glacial Maximum. Nature 400, 248-250. 
Sowers, T., Alley, R.B., Jubenville, J., 2003. Ice core records of atmospheric N2O covering the last 106,000 years. Science 301, 945-948.

Spero, H.J., Lea, D.W., 2002. The cause of the carbon isotope minimum events on glacial terminations. Science 296, 522-525.

Stocker, T.F., Johnsen, S.J., 2003. A minimum thermodynamic model for the bipolar seesaw. Paleoceanography 18.

Stocker, T.F., 1998. Climate change - The seesaw effect. Science 282, 61-62.

Strub, P.T., Mesias, J.M., Montecino, V., Ruttlant, J., Salinas, S., 1998. Coastal ocean circulation off Western South America. In: Robinson, A.R., Brink, K.H. (Eds.), The Global Coastal Ocean. Regional Studies and Syntheses. Wiley, pp. 273-315.

Timmermann, A., Krebs, U., Justino, F., Goosse, H., Ivanochko, T., 2005. Mechanisms for millennial-scale global synchronization during the last glacial period. Paleoceanography 20.

Timmermann, A., Okumura, Y., An, S.-I., Clement, A., Dong, B., Guilyardi, E., Hu, A., Jungclaus, J.H., Renold, M., Stocker, T.F.,
Souffer, R.J., Sutton, R., Xie, S.-P., Yin, J.H., in press. The influence of a weakening of the Atlantic meridional overturning circulation on ENSO. J. Climate.

Toggweiler, J.R., Rusell, J.L., Carson, S.R., 2006. Midlatitude westerlies, atmospheric $\mathrm{CO} 2$, and climate change during ice ages. Paleoceanography 21, PA2005. doi:10.1029/2005PA001154.

Tomczak, M., Godfrey, J.S., 2003. Regional Oceanography: An Introduction. Daya Pub.

Visser, K., Thunell, R., Stott, L., 2003. Magnitude and timing of temperature change in the Indo-Pacific warm pool during deglaciation. Nature 421, 152-155.

Weaver, A.J., Saenko, O.A., Clark, P.U., Mitrovica, J.X., 2003. Meltwater pulse 1A from Antarctica as a trigger of the bollingallerod warm interval. Science 299, 1709-1713.

Wolff, E.W., et al., 2006. Southern Ocean sea-ice extent, productivity and iron flux over the past eight glacial cycles. Nature 440, 491-496.

Yin, J.H., 2005. A consistent poleward shift of the storm tracks in simulations of 21 st century climate. Geophys. Res. 32 . 